\title{
Conservation Status of Dilifekar Block, Arsi Mountains National Park, Ethiopia
}

\author{
Getachew Bantihun ${ }^{1}$, Shimekit Tadele ${ }^{2} *$ \& Abebe Ameha Mengistu ${ }^{3}$ \\ ${ }^{1}$ Adama Science and Technology University, School of Applied Natural Sciences, \\ Department of Applied Biology, Adama, Ethiopia. \\ ${ }^{2}$ Adama Science and Technology University, School of Applied Natural Sciences, \\ Department of Applied Biology, Adama, Ethiopia. \\ ${ }^{3}$ Adama Science and Technology University, School of Applied Natural Sciences, \\ Department of Applied Biology, Adama, Ethiopia.
}

\begin{abstract}
*Corresponding Author: Shimekit Tadele, Adama Science and Technology University, School of Applied Natural Sciences, Department of Applied Biology, Adama, Ethiopia.
\end{abstract}

\begin{abstract}
This study was conducted at Dilifekar Block, Arsi Mountains National Park focuses on the contribution and the perception of the local communities towards the conservation efforts and its sustainable values. The data in the current study were collected through focus group discussion. From focus group discussion of 42 local inhabitants, $47.6 \%$ responded mammals, among the vertebrate groups, are highly vulnerable to the death on the road with cars. $73.8 \%$ of the respondents agreed that the conservation of the Block is important and beneficiary. From the assessment of the office of the Block management body and from the observation of the Block arena, it was possible to know that the office is trying to improve the conservation activities from time to time and trying to safeguard the wildlife by fencing. But the level of awareness creation of the local community is still very important assignment for the management body of the Block.
\end{abstract}

Keywords: Block, Community, Conservation, Dilifekar.

\section{INTRODUCTION}

The aim of the world conservation strategy is focused primarily to conserve natural resources, mainly to preserve genetic diversity, to maintain essential ecological processes and to ensure sustainable utilization of species and ecosystems at large [1]. With the same report to astonishingly, the development efforts of many developing countries, including Ethiopia are being slowed by lack of proper conservation. Environmental modification like in mode the days' so called forest clearing speculations all not mean to lead developments. Unless it is directed by ecological, environmental, social, cultural and ethical, friendly considerations, much improvement will continue to have undesired effects, to supply reduced reimbursements or otherwise to fall short altogether [1,2].

Compiled report on African wildlife foundation attempted that in East Africa many of the most significant protected areas are found neighboring pastoral land use systems [3]. In line with, increasing of human population, and related negative land pressures, has been resulting in the shrinking of natural resources as a whole. The conservation strategy based on the joint between the local community and conservation authorities is known to be the best management strategy in principle to conserve and earn benefit in a sustainable approach; however, the participation of local peoples in this regard is very less in past decades.

It is also stated in the different literature that protected areas are the most common device for in situ conservation of biodiversity globally. Against to the affirmative sense of establishing protected areas, social promoters disagree that protected areas take away local rights of access to critical resources and thus negatively, and unjustly, crash the social and economic welfare of neighboring communities. This negative human impact, so the argument goes, troubles protected area conservation objectives 
because protected areas cannot succeed without an involvement of local communities, and since then poverty, which is exacerbated by protected areas is a root cause of ecosystem degradation $[4,5]$. Altering the landscapes due to the extensive cattle ranching directly leads to deforestation and the main cause of loss of wildlife habitats. Thus, different works literatures reasonably in broad view quote geomorphologic changes and negative impacts for wildlife groups [6].

The establishment and expansion of protected areas in Ethiopia have been motivated to save genetic resources and abundance of varieties of wildlife through investigations. The objective of this management was to protect wild animals and natural habitats through restriction of unlimited destruction of local communities. Currently, the country has a total of 61 protected areas. Among these 11 are national parks managed by the Ethiopian Wildlife Conservation Authority (EWCA), 13 national parks and sanctuaries managed by the regions, 3 biosphere reserves, 2 wildlife sanctuaries managed by the regions, 6 wildlife reserves managed by the regions, 6 open controlled hunting areas managed by the regions [7]. Even though this, however, national policy for protected areas and management activities is affected by many negative factors in the country such as inadequate financial support to protected area management linked to the priorities and difficulties of national economy, poor communities in and around protected areas, less emphasis and non involvement of local communities in conservation actions, problems related to national land use plan have brought some limitations to moving towards international criteria and principles.

The effective management of wild species, either flora or fauna of a park can be greatly improved by the periodic studies and knowledge of the entire population distribution and abundance. Therefore, this is study is focusing on conservation efforts and status of the Dilifikar Block with a hypothetical diagram of local communities and expected values.

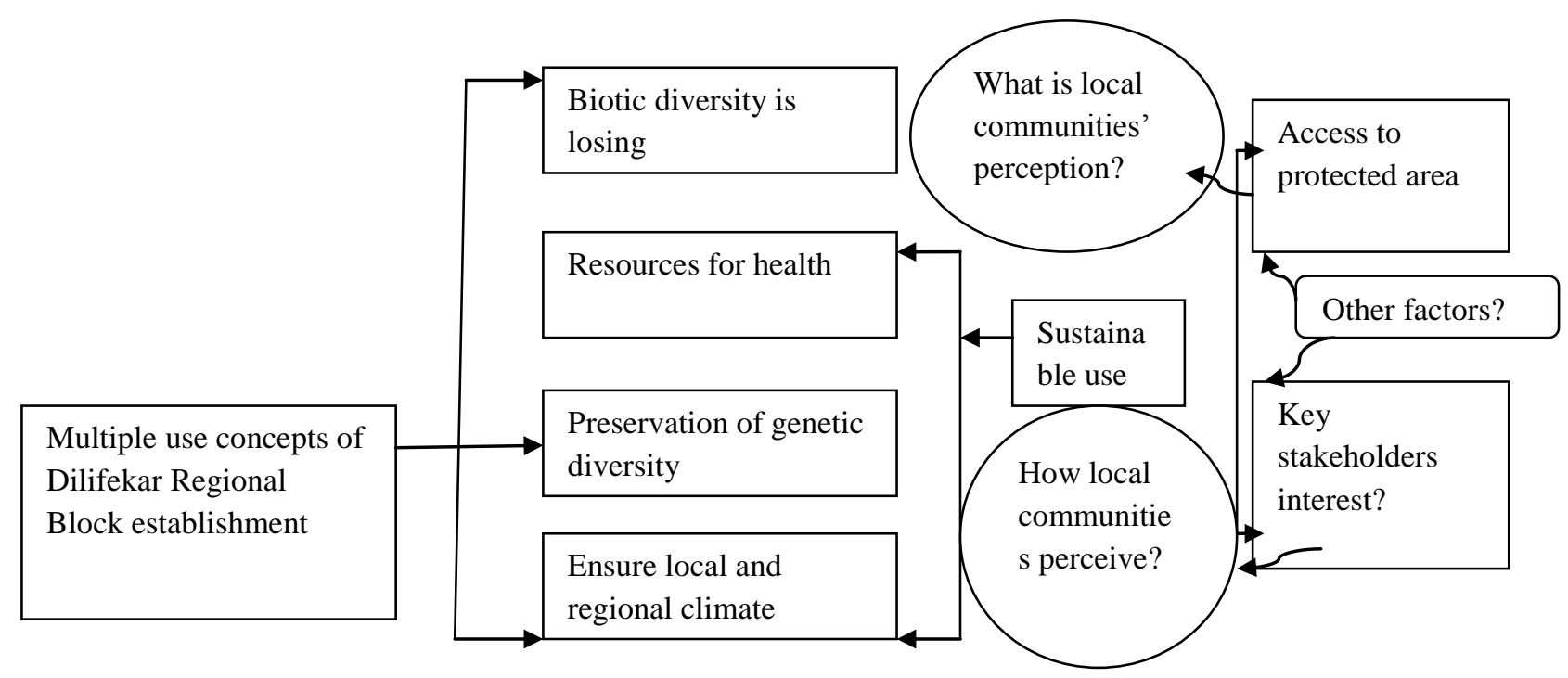

Figure 1. Conceptual hypothetical model for the study

\section{MATERIALS AND MethodS}

\section{The Study Area}

The study was carried out in Dilifekar Regional Block, Arsi Mountains National Park, Ethiopia. Dilfekar Park is one of the four (Chilalo-Galama, Kaka, Hoqolo and Dilfekar) Arsi Mountains National Parks. The total area covered is 1341 ha. It is situated $125 \mathrm{~km}$ south of Addis Ababa, and 55 $\mathrm{km}$ north of Asella, the Zonal capital. It is only $15 \mathrm{~km}$ from Sodere resort center [8]. It is located at $8^{0} 20^{\prime} 30.88^{\prime \prime} \mathrm{N} 39^{\circ} 19^{\prime} 44.85^{\prime \prime} \mathrm{E}$ and has an altitude ranging between $2200-2400 \mathrm{~m}$ above the sea level [9].

Concerning the vegetation cover of the park, generally it is scattered acacia wooded grassland. Some of the trees and shrubs found in the park are Balanites aegyptica, Acacia senegal, Strychnos spinosa (monkey orange), Ficus sycomorus, Euphorbia abyssinica, Opuntia ficus-indica, Acacia abyssinica, Solanum habrochaites, Acacia seyal, Terminalia brownie. The dominant grass is Hyparrhenia genus. 


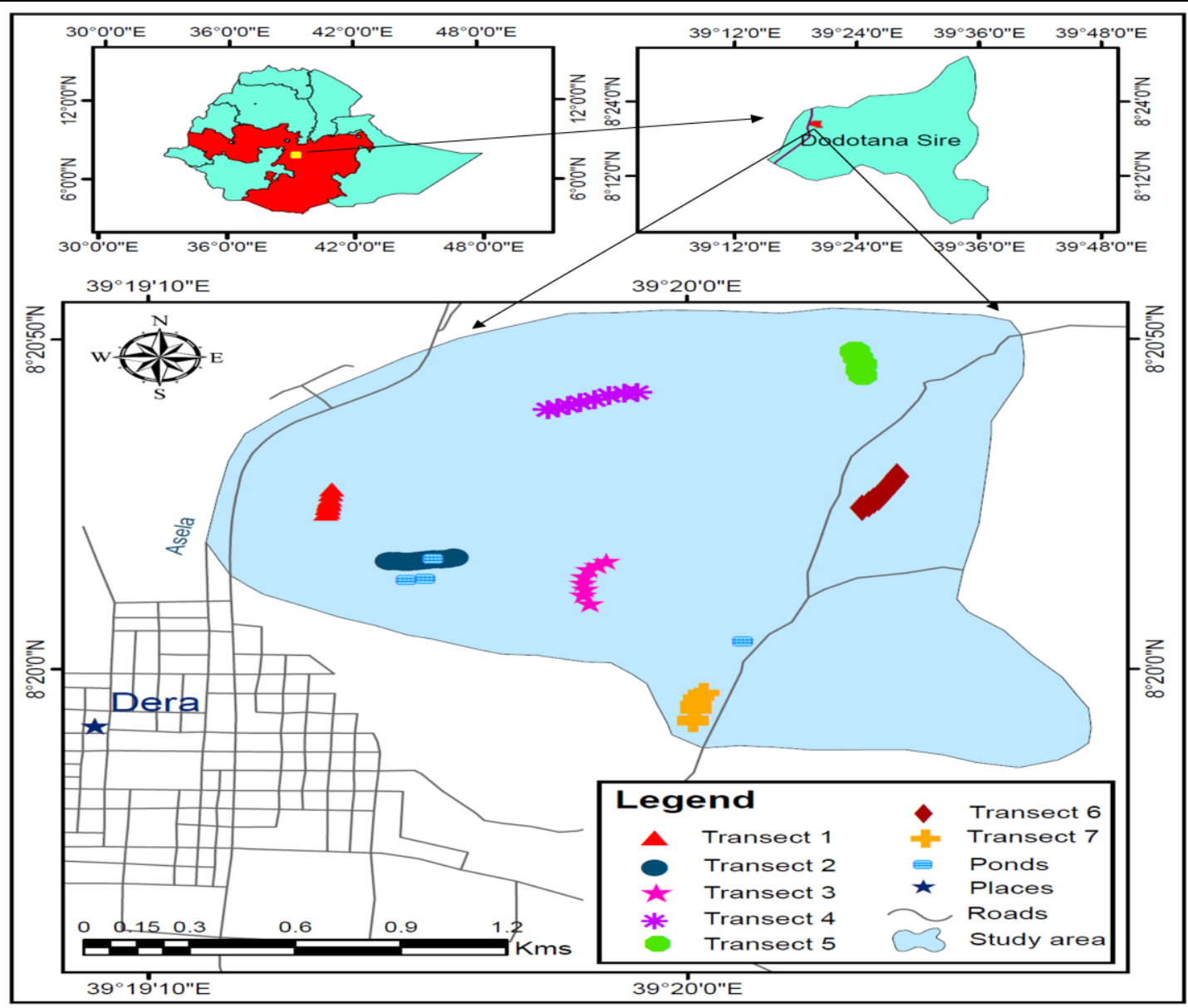

Figure 2. Map of the study area

\section{Data Collection Methods}

We conducted a purposive sampling technique to generate data from the respondents of the study area by involving 42 peoples, among these 30 were local people with responsibility given to play a role in the protection of the Park. The remaining 12 people were the staff of the Park. Data was produced by focus group discussion and interview administered questionnaire for both the local peoples who are involved to supervise sequentially in surrounding of the Park and employees. The questionnaire was designed to evaluate the knowledge, perception and attitude towards the Park and inhabiting wild vertebrate groups. Particularly, major threats to wildlife were interviewed to understand the level of management and conservation gaps.

Thus, staff members of the Park and participating local peoples as a stake were taken as information sources of our study area. The reason for limiting our data source only with those involved in the Park area was due to an assumption of efficient information along with since the recent establishment of the Park area. Focus group discussion was carried by the local language, Amharic, and responses were recorded andtranslated later into English. Data were presented as the percentage (\%) given each response. Chi-square $\left(\chi^{2}\right)$ tests were applied to get out if the responses occurred with like probability.

\section{RESULTS AND DISCUSSION}

In order to supplement conservation status, the study entertained staffs of the Block management and local communities by both questionnaires and focus group discussions. As it is presented in Table 1, $47.6 \%$ of respondents said that the death of the mammals, either it is a small sized or large sized mammalian groups, of the Block is high on the road which indicates that the design of the road and awareness of the car drivers towards wild vertebrate groups is still confined. This might be due to reasons of movement of animals by crossing the road which has directly led to victims. Road kill data between vertebrate groups is statistically significant $\left(\chi^{2}=12.95, \mathrm{df}=3, \mathrm{p}<0.05\right)$. Reptiles are also vulnerable to road kill agents; this was reported by $26.2 \%$ of respondents. High vertebrate diversity strike by a road accident is a great concern for conservation and sustainability of some rare species. [10] Found that 72 species of vertebrate groups killed by road accidents, of which, 40 species were 
birds, 24 species of mammals and 8 of reptiles related to landscape characteristics. To reduce the car accidents, it seems sound loudly to make car speed breakers on the road where the road by its geographical set up from the direction of Asella to Adama invites the car drivers use high speed.

Table 1. Road Kill factors of Vertebrate groups of Dilfekar Block

\begin{tabular}{|l|l|l|}
\hline Vertebrate groups killed on road & Frequency & Percentage \\
\hline Amphibians & 6 & 14.3 \\
\hline Reptiles & 11 & 26.2 \\
\hline Birds & 5 & 11.9 \\
\hline Mammals & 20 & 47.6 \\
\hline
\end{tabular}

As our study area is semi-dry land, water scarcity is reported as the highest with $54.8 \%$, and the factor of prey is reported as the least, $4.8 \%$ (Table 2).

Table 2. Reported significant factors to wild vertebrate groups

\begin{tabular}{|l|l|l|}
\hline Reported threats & Frequency & Percentage \\
\hline Vehicle accident & 3 & 7.1 \\
\hline Prey & 2 & 4.8 \\
\hline Habitat loss & 4 & 9.5 \\
\hline Scarcity of water & 23 & 54.8 \\
\hline Grazing & 10 & 23.8 \\
\hline
\end{tabular}

Grazing in the Park has also resulted in $23.8 \%$ as a pessimistic factor in the diversity of vertebrate groups of the wildlife.

Concerning the measures which have been taken by Block managers for threat reduction, about $57.1 \%$ of respondents reported that, fencing as a key technique to manage the Block and also to alleviate road kill threats. According to the respondants, while the least and unmanageable threat was a vehicle speed reduction. Public education and awareness based technique is growing up and reported as effective mitigation technique, $35.7 \%$ (Table 3 ).

Table 3. Current mitigation techniques to reduce road impacts

\begin{tabular}{|l|l|l|}
\hline Reported techniques & Frequency & Percentage \\
\hline Fencing & 24 & 57.1 \\
\hline Vehicle Road speed reduction & 0 & 0 \\
\hline Public education and awareness & 15 & 35.7 \\
\hline Public transit & 3 & 7.1 \\
\hline
\end{tabular}

The level of community's perspective and understanding towards the wildlife resources and benefits was strong, $73.8 \%$ of respondents agreed with conservation of the wildlife (Table 4). The local communities strongly and positively support the positive benefits of the Block; this might be due to for firewood collection, grass collection and indirect income from the Park, as a tourist site and to advertise their cultures. This Block was very young and before established as protected area, the local communities were using as animal graze site, residential site and farm land. Similarly, different scholars reported the positive influence of local communities from the Park area, e.g. [11, 12, 13].

Table 4. Level of awareness regarding benefits of wildlife of Dilfekar Block to the community

\begin{tabular}{|l|l|l|}
\hline Attitudinal report of wildlife and its benefits & Frequency & Percentage \\
\hline Strongly shares benefits & 31 & 73.8 \\
\hline No benefit & 5 & 11.9 \\
\hline Better to use this park for farming & 6 & 14.3 \\
\hline
\end{tabular}

In contrast, $11.9 \%$ of respondents reported as the Park has no any benefit from the wildlife and conservation activities. [14] Reported negative attitudes of local communities towards conservation of National Parks due to reasons of loss of job opportunities, proximity of community settlement and related factors. Some communities have less awareness towards protection of the area by comparing the pervious benefits before the Block establishment.

In this study, it tried thatto document the traditional management techniques. As shown on Fig. 3, the Dilfekar Block has been managed by different punishment types. While local peoples grazing their 
livestock, $90.5 \%$ of livestock owners were paying some money, otherwise still there was no officially taxed fee collection and punishment by the Block management bodies. If this punishment can be strengthened, it might help to secure wildlife and increase diversity of the species of the area.

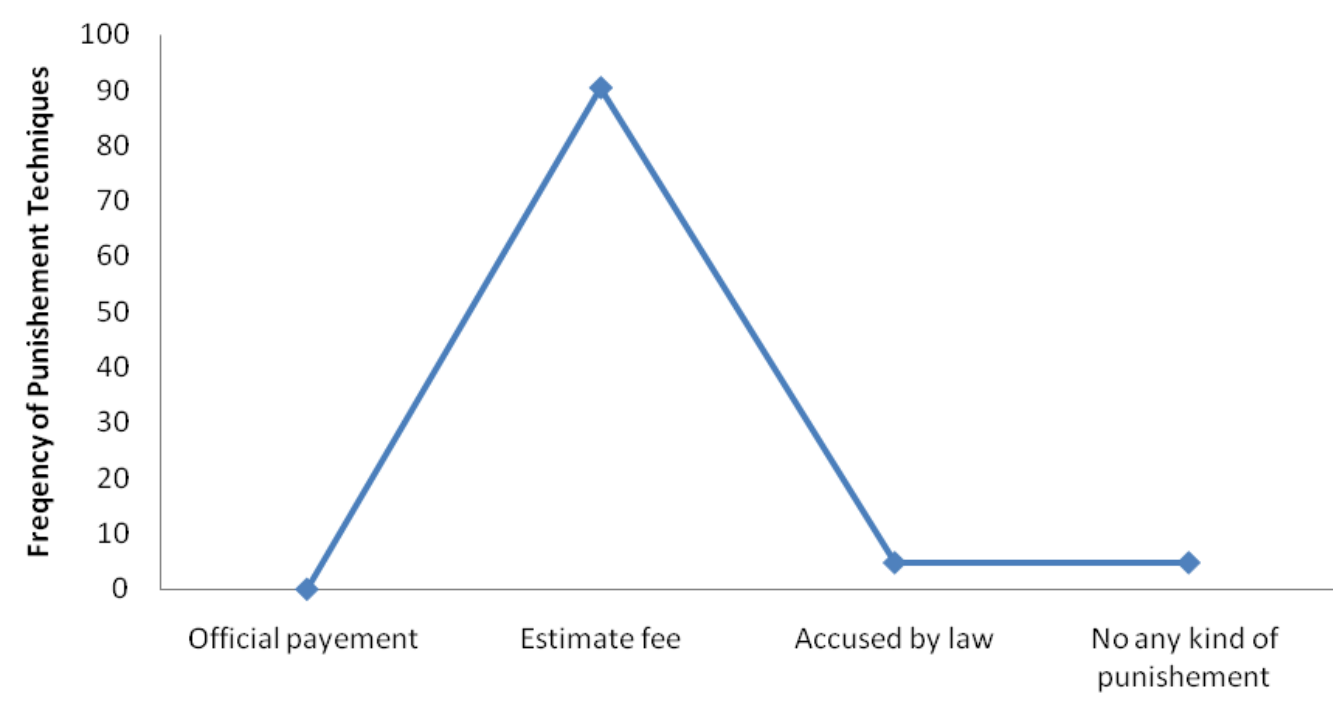

Types of Punishement

Figure 3. Report of punishment techniques by Park management while communities' grazing their livestock's inside the Park

Due to increased anthropogenic pressure and very dry area around Dehra area, there is competition between livestock with wildlife and human beings for the resources. The salvation of this factor was managed by restricted incarceration of livestock's until owners make a payment for the release of their own livestock's'. This approach can be considered as a restrictive way till perception is to be solid with local communities about conservation and in another way as a generation of income for the Block. These strategies could be potentially enforced unruliness or resistance as a general human attitude towards conservation within the protected area [15].

Table 5 clearly presents the level of intensive grazing among different seasons. The summer season, July-September was the period for grazing and the habitat of wildlife was mostly affected. This was supported by $69 \%$ of respondents. In another way grazing level was loweredabout $4.8 \%$ from the month January to June. Intense grazing of the Block area by livestock during the wet season was due to coverage of farmland areas of crops. Nearby surrounded residents consciously send their livestock's to the Park area to forage, this might account as a great influence during the wet season.

Table 5. Intensive grazing periods by the livestock

\begin{tabular}{|l|l|l|}
\hline Level of intensive grazing & Frequency & Percentage \\
\hline July-September & 29 & 69 \\
\hline October-December & 9 & 21.4 \\
\hline January- March & 2 & 4.8 \\
\hline 2 & 2 & 4.8 \\
\hline
\end{tabular}

The life style of the wildlife and the habitat conservation status was also assessed. About $85.7 \%$ of respondents reported that the status of conservation and management style is improving, some $4.8 \%$ of respondents reported as the habitat was not shown a progress. As it was shown in Table 6, none of the respondents were responded high status of improvement. One approach and supportive rationale for improvement progress might be very short history of its establishment and restoration activities from 70 ha since 1975 to the current total area coverage of 1,341 ha [8].

Table 6. Report on conservation and habitat improvements within five years

\begin{tabular}{|l|l|l|}
\hline Observed changes of the Park & Frequency & Percentage \\
\hline Highly improving & 0 & 0 \\
\hline Improving & 36 & 85.7 \\
\hline Degrading & 4 & 9.5 \\
\hline No change & 2 & 4.8 \\
\hline
\end{tabular}


To have some information of the Block value and utilization, this study had collected ways of revenue sources. The study area was visited by foreigners, both resident and non residents and students. As it was presented in figure 4, the visit of foreigners was continuously increased from the year 2012-2015, similarly university students visit was also increased from year to year. In contrary, visit by Adult Ethiopians was decreased from year to year as per the raw data obtained from the Block management offices. This might be the sign for the management offices of the Block to make more effort for in the attraction activities to gain the deserved benefits from the Block. According to [16], accommodation, Park entry fee and catering services are the major sources of revenues in the Park. [17] reported that economic valuation of protected areas from tourist can lead to the appreciation of the values of other protected areas. Visit frequency by Ethiopian adults was declining from year to year; this might be due to feeling of charge fee. According to [18], it is simply not appropriate to charge citizens to access public land. This non fee principle might be for developed nations; however, in the Ethiopian case protected areas are important as job opportunities and also income generation from different source type of fee.

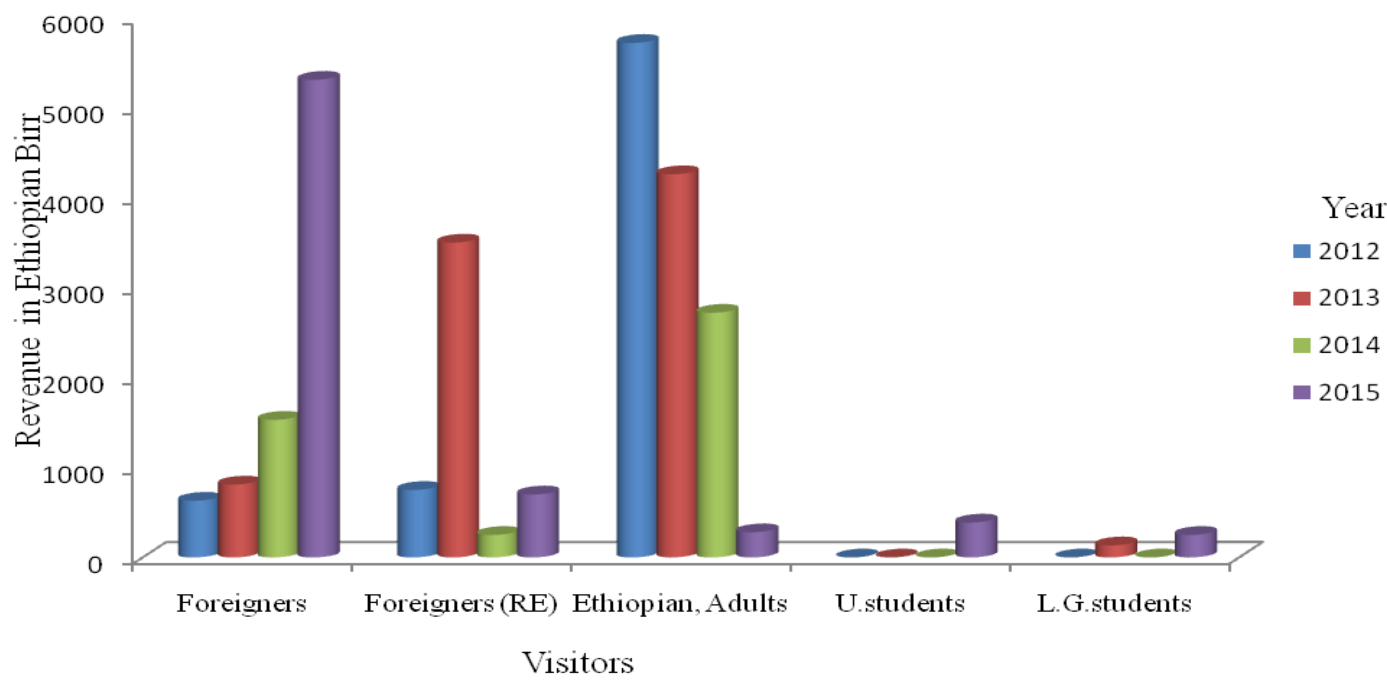

Figure 4. Revenue from entry fee from Dilfekar Block

Key: Foreigner (RE) Ethiopian: Foreigner Residence Ethiopian, U. students: University Students, L.G. students: Lower Grade students

As presented in the Table 7, the Block is collecting more money from local communities by punishing livestock owners. The level and amount of revenue were increased from year to year. It seems the Block managers are seriously paying an attention to conserve it, since 72775 Ethiopian Birr (ETB) was collected in 2015 than 33,330 Ethiopian Birr (ETB) which was collected in 2013.

Table 7. Other type of Revenue from the Park

\begin{tabular}{|l|l|l|l|}
\hline \multirow{2}{*}{ Type of Revenue earning } & \multicolumn{2}{|l|}{ Year } & 2015 \\
\cline { 2 - 4 } & 2013 & 2014 & 72775 \\
\cline { 2 - 4 } & Amount of Revenue in ETB & 535 \\
\hline Live stock Incarceration, Punishment & 33,330 & 50,903 & 470 \\
\hline Vehicle entrance fee & 0 & 0 & 0 \\
\hline Tent camping fee & 0 & 0 & \\
\hline
\end{tabular}

$\mathrm{ETB}=$ Ethiopian Birr

This study has concluded that realization of jointly local community based program for the protection of wildlife resources is better than only fencing and effort by conservation authorities. Moreover, conservation of wildlife and the whole habitat of the study area are improved if collaboration is made among local communities and conservation organization. Generally, the conservation efforts being made by the stakeholders of the Dilifeqar Block are better yet, but need further improvement.

\section{ACKNOWLEDGMENTS}

We thank all the respondents of the research questions of this study. We also thank Adama Science and Technology University for the financial funding. We are also thankful to Oromia Forest and 
Wildlife Enterprise and Arsi Mountains National Park, Dilifekar Block for its willingness for the study to be conducted

\section{REFERENCES}

[1] International Union for Conservation of Nature and Natural Resources (1980). World conservation strategy: Living resource conservation for sustainable development. Gland, Switzerland. Pp 77.

[2] Erol, S. Y., Kuvan, Y. and Yildirim, H., T. (2011). The general characteristics and main problems of national parks in Turkey. African Journal of Agricultural Research, 6, 5377-5385.

[3] Barrow, E., Lembuya, P., Ntiati, P. and Sumba, D. (1994). Knowledge, attitude and practices concerning community conservation in the group ranches around Amboseli National Park. African Wildlife Foundation Discussion Papers CC-DP-11, Pp 1-36.

[4] West, P., Igoe, J. and Brockington, D. (2006). Parks and Peoples: The Social Impact of Protected Areas. Annual Review of Anthropology, 35, 251-77.

[5] Ferraro, P. J. (2008). Protected Areas and Human Well-Being. Economics and Conservation in the Tropics: A Strategic Dialogue: Conference paper, Georgia State University, Atlanta.

[6] Fischer, M. G., Codesido, G. M. and Bilenca, D. (2012). Seasonal variations in small mammal-landscape associations in temperate agro ecosystems: a study case in Buenos Aires province, central Argentina. Mammalia, 76, 399-406.

[7] Vreugdenhil, D., Vreugdenhil, A.M., Tamirat Tilahun, Anteneh Shimelis, Zelealem Tefera (2012). Gap Analysis of the Protected Areas System of Ethiopia. World Institute for Conservation and Environment, USA.

[8] ASDA and ABRDP. (2006). Social Survey of Community-Based NRM in Five Kebeles Adjacent to the Dilfekar Regional Park, Dodota Sire Woreda. Association for Sustainable Development Alternatives (ASDA) and Arsi Bale Rural Development Project (ABRDP).

[9] Addisalem Benyam (2011). Evaluating the UNDP - GEF Small Grants Programme Funding in Ethiopia: Sustainable Livelihoods and Poverty Alleviation in Action. MSc thesis. University of Manitoba Winnipeg, Manitoba.

[10] Freitas, S.R., Sousa, C.O.M., and Bueno, C. (2013). Effects of landscape characteristics on road kill of mammals, birds and reptiles in a highway crossing the Atlantic forest in Southeastern Brazil. Proceedings of the 2013 International Conference on Ecology and Transportation (ICOET 2013) Pp 1-11.

[11] Mesele Yehun (2006). Human-Wildlife (the Ethiopian Wolf and Gelada Baboon) Conflict in and around the Simien Mountains National Park. MSc Thesis, Addis Ababa University, Addis Ababa.

[12] Yosef Mamo (2014). Attitudes and perceptions of the local peoples towards benefits and conflicts they get from conservation of the Bale Mountains National Park and Mountian Nyala, Ethiopia. International Journal of Biodiversity and Conservation, 7, 28-40.

[13] Namukonde,N. and Kachali,R.N.(2015). Perceptions and attitudes of local communities towards Kafue National Park, Zambia. PARKS, 21, 25-36.

[14] Macura, B., Zorondo-Rodríguez, F. Grau-Satorras, M. Demps, K. Laval, M., Garcia,C.A., and ReyesGarcía,V., (2011).Local community attitudes toward Forests outside protected areas in India. Impact of legal awareness, trust, and participation. Ecology and Society 16: 10.

[15] Szell, A. B. and Hallett, L. F. (2013). Attitudes and Perceptions of Local Residents and Tourists toward the Protected Area of Retezat National Park, Romania. International Journal of Humanities and Social Science, 3, 18-34.

[16] Ajibade W. A., Ayodele I. A., Ojo S. O. and Adetotor A. O. (2013). Wildlife based tourism activities and income generation in Kainji Lake National Park, Nigeria. African Journal of Agricultural Research, 8, 6435-6438.

[17] Navarro, G. M., Paca E.D.and Rimas, C. (2007). The eco-tourism value of National Park: a case study from the Philippines. Pp 32

[18] Lindberg, K. (2001). Protected Area Visitor Fees. Cooperative Research Centre for Sustainable Tourism, Griffith University. Pp.33

Citation: G. Bantihun et al., " Conservation Status of Dilifekar Block, Arsi Mountains National Park, Ethiopia

", International Journal of Research in Environmental Science, vol. 4, no. 1, p. 20-26, 2018. http://dx.doi.org/ 10.20431/2454-9444.0401003

Copyright: (C) 2018 Authors. This is an open-access article distributed under the terms of the Creative Commons Attribution License, which permits unrestricted use, distribution, and reproduction in any medium, provided the original author and source are credited. 